\title{
SEASONAL CHANGES IN THE CHEMICAL COMPOSITION OF THE DEFENSIVE SECRETION OF THE RICE PEST LEPTOCORISA ORATORIUS (HEMIPTERA:COREIDAE)
}

\author{
NEELAKANTHI E. GUNAWARDENA \\ Department of Chemistry, University of Kelaniya, Kelaniya.
}

(Received : 16 November 1993; acceped: 28 July 1994)

\begin{abstract}
The defensive secretion emitted by the rice bug, Leptocorisa oratorius Fabricius (Hemiptera: Coreidae) during the non-season (when the pest is on host plants other than rice plant, Oryza sativa L.) was analyzed by combined gas liquid chromatographic-mass spectrometric analysis. The results revealed that during this period both male and female $L$. oratorius did not possess t-2-hexenal and n-octylacetate, which are characteristic of the defensive secretion during the season (when the pest is on rice plant, the most favoured food source). A mixture of $\mathbf{n}$-alkanes is present instead. The male secretion consisted of 37 compounds of which the most prominent compounds were n-decane (3\%), n-undecane (5\%), n-dodecane $(8 \%)$, $n$-tridecane $(9 \%)$ and $n$-tetradecane $(7 \%)$ whereas the female secretion showed 84 compounds of which above n-alkanes in the above order were present in $7 \%, 7 \%, 7 \%, 5 \%$ and $3 \%$ respectively.
\end{abstract}

Key words: Leptocorisa oratorius, rice pest, defensive secretion, $n$-alkanes.

\section{INTRODUCTION}

Among the pests associated with the developing rice (Oryza sativa L.) panicle, Leptocorisa oratorius Fabricius (Hemiptera: Coreidae) is one of the most serious pests in the Asia-Pacific region., ${ }^{1,2}$ In this region $L$. oratorius has, on some occasions, caused crop losses as high as $50 \% .^{3}$ In Papua New Guinea, it has been reported to cause damage to $90 \%$ of rice grains. ${ }^{4}$ There is no environmentally accepted method for the control of this pest. Only a few chemical ecological studies have been devoted to this pest viz. a preliminary investigation of a host attractant and the defensive secretion during the season. ${ }^{5,6}$

Rice is the best host for $L$. oratorius resulting in the most favourable growth index, greatest fecundity and highest number of stylet sheaths. ${ }^{7}$ L. oratorius is attracted to rice fields when the rice plant starts producing milk in its panicles. The growing rice grain is the favored food of this pest and the pest population reaches its maximum density while feeding on developing rice grains. After harvest the insect returns to shady areas and survives on other plants such as grassy weeds. During this period the pest population reaches a minimum and the insect becomes thin and light in colour.

The defensive secretion of this pest during the season (on the rice plant) has been reported to consist of a mixture of $t$-2-octenal and $n$-octylacetate ( $76 \%$ and $16 \%, \mathrm{w} / \mathrm{w}$ respectively) and to possess moderate insecticidal and repellent properties. ${ }^{6}$ Preliminary investigations suggested that the secretion of $L$. oratorius during the non-season was different from that produced during the season. I report here the chemical composition of the secretion of $L$. oratorius during the non-season. 


\section{METHODS AND MATERIALS}

Collection of the defensive secretion: L. oratorius was collected from grassy weeds in the Kurunegala District two months after the rice season. The defensive secretion was collected by placing each male or female $L$. oratorius in a pre-weighed small glass vessel and keeping it at $-5^{\circ} \mathrm{C}$ for $5 \mathrm{~min}$. After this time the defensive secretion was seen emitted on to the walls of the glass vessel. The insect was removed from the vessel immediately after the emission and the vessel was kept at $-20^{\circ} \mathrm{C}$ until chemical analysis.

Chemical analyses: GC of the defensive secretion was performed on Hewlett Packard 5890 A gas chromatograph fitted with SE 54 fused silica capillary column $(25 \mathrm{~m} \times 0.25 \mathrm{~mm})$, FID detector, injector $220^{\circ} \mathrm{C}$, detector $260^{\circ} \mathrm{C}, 60^{\circ} \mathrm{C}$ to $260^{\circ} \mathrm{C}$ at $8^{\circ} \mathrm{C} / \mathrm{min}, 10 \mathrm{~min}$ at $260^{\circ} \mathrm{C}$, Combined gas chromatographic-mass spectrometric ( GC-MS) analysis was performed on Finnigan MAT 90 quadrapole mass spectrometer coupled to a Varian 3400 chromatograph equipped with $25 \mathrm{~m} \mathrm{x} 0.22 \mathrm{~mm}$ fused silica column-coated with SE-52 stationary phase, carrier gas $\mathrm{He}$, temperature programme as above.

\section{RESULTS}

General features: Insects collected during the non-season were not active, fairly thin and emitted lesser amounts of the defensive secretion $(<0.5 \mathrm{mg} /$ insect) than those during the season ( $>1 \mathrm{mg} /$ insect). The defensive secretion during the non-season did not have the characteristic smell of the secretion obtained in the season.

Chemical analyses: GC analysis of male secretion showed 37 peaks and that of female showed 84 peaks (Figs. $1 \mathrm{~A}$ and $\mathrm{B}$ respectively). Of the large number of peaks only six were prominent. The peaks were identified from the mass spectra:

$$
\begin{array}{ll}
n \text {-decane }(\mathrm{m} / \mathrm{z}): & 142.1(10 \%), 98.1(5 \%), 85(21 \%), 71(30 \%), 57(100), 43(94 \%) \\
n \text {-undecane }(\mathrm{m} / \mathrm{z}): & 156(10 \%), 135(2 \%), 98(5 \%), 85(22 \%), 71(40 \%), 57(98 \%), \\
& 43(100 \%) . \\
& 170(8 \%), 133(2 \%), 98(1 \%), 85(23 \%), 71(42 \%), 57(100 \%), \\
& 43(97 \%)
\end{array}
$$

n-tetradecane $(\mathrm{m} / \mathrm{z}): \quad 198(12 \%), 127(2 \%), 99(5 \%), 85(38 \%), 71(58 \%), 57(100 \%)$, $43(82 \%)$.

The retention time $(\mathrm{min})$ comparison with those of the authentic (given in parentheses) were as follows: $n$-decane 6.65 (6.69); $n$-undecane 9.57 (9.59); $n$-dodecane 12.34 (12.37); $n$-tridecane 14.89 (14.91); $n$-tetradecane 17.25 (17.24). 

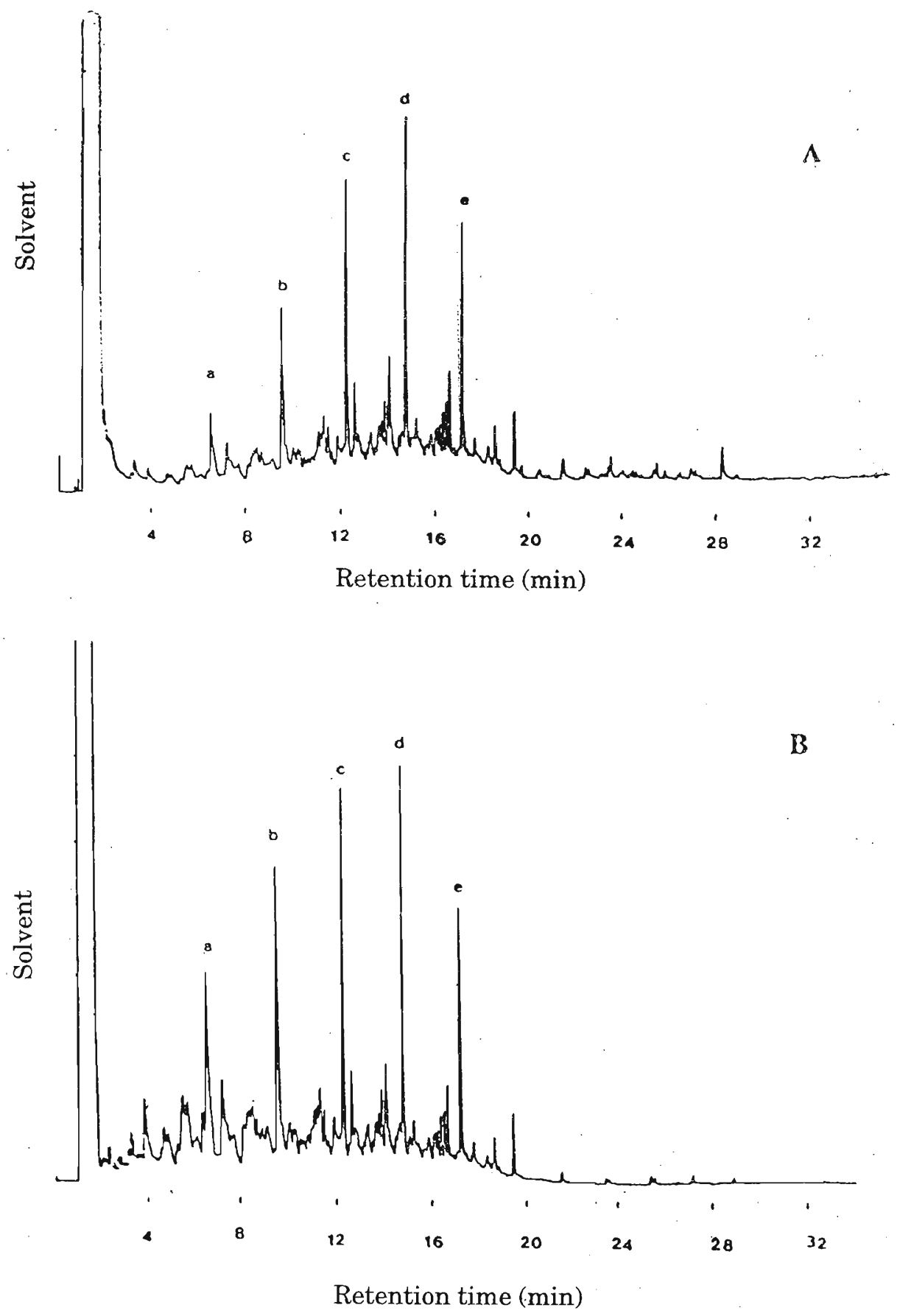

Figure $1 \mathrm{~A}$ and 1B: Respective gas chromatograms of the defensive secretion of male and female $L$. oratorius during non-season.

$\mathrm{a}=\boldsymbol{n}$-decane, $\quad \mathrm{b}=\boldsymbol{n}$-undecane, $\quad \mathrm{c}=\boldsymbol{n}$-dodecane,

$d=n$-tridecane, $e=n$-tetradecane: 


\section{DISCUSSION}

The results show that during the non-season $L$. oratorius possess a secretion which consists of a mixture of $n$-alkanes in contrast to the characteristic defensive secretion present during the season consisting of a mixture of $t$-2-octenal and $n$-octyl acetate. The occurrence of the $n$-alkanes from C-10 to C-13 together with one or more volatile irritants such as alkenals/alkanals is common among hemipteran defensive secretions. ${ }^{9}$ Several function have been allocated to $n$-alkanes viz, serving as the solvent that modulatse evaporation of volatile irritant, penetrating agent of the defensive secretion through the cuticles of enemies. ${ }^{10}$ In a recent study it was proved that C-11, C- 12 and $\mathrm{C}-13$ are best suited as the accompanying compounds. ${ }^{11}$ However the occurrence of alkanes without a deterrent is rather rare. Among 60 species of hemipterans surveyed in this study only one species, Capocoris purpureipennis (Pentatomidae) used tridecane alone in its defensive secretion. ${ }^{12}$

The defensive function of the secretion of $L$. oratorius during the season was established by us previously. ${ }^{6}$ It is unlikely however, that the secretion during the non-season would have powerful repellent or deterrent properties because such compounds were not detected during this time. Reports on defensive secretions of hemipterans during non-season are rather obscure and therefore the exact function of this defensive secretion is not quite apparent. Aggregation behaviour ${ }^{13,14}$ and the use of alarm pheromones ${ }^{15}$ among coreids is well documented. Perhaps the secretion under consideration may have indirect defensive function such as an aggregation or alarm pheromone activity. Supporting this suggestion is the finding that $n$-tridecane has been reported to behave as a bifunctional pheromone in the southern green stink bug, Nazara viridula. $n$-tridecane behaves as an aggregation dispersal as well as an attractant pheromone for the above insect depending on the concentration used. ${ }^{16}$

\section{Acknowledgement}

The author thanks the Alexander von Humboldt Foundation for a fellowship, International Foundation for Science (Sweden) for a research grant (F/936-1) and Prof. H J Bestmann of the Institute of Organic Chemistry, University of Erlangen Nurnberg, Germany for providing analytical facilities.

\section{References}

1. Grist D. H. \& Lever R. J. A. W. (1969). Pests of rice, (Tropical Sciences Series,) Longmans Green, London.

2. Srivastava A.S. \& Saxena H.P. (1967). Rice bug, Leptocorisa varicornis and allied species. In Major Insect Pests of the Rice Plant. pp. 525-548. John Hopkins Press, Baltimore.

3. Banerjee S.N. (1957). On the incidence of paddy pests in West Bengal. Proceedings of the Zoological Society, Calcutta. 9: 65-83. 
4. Sands D.P.A. (1977). The biology and ecology of Leptocorisa (Hemiptera: Flydidae) in Papua New Guinea In Rice Research Bulletin, Department of Primary Industry, Papua New Guinea, No. 19, pp 104.

5. Gunawardena N. E. \& Ranatunga P.R. (1989). Laboratory and field studies of a natural attractant of the rice pest, Leptocorisa acuta, (Hemiptera: Coreidae). Tropical Pest Management 35: 212-213.

6. Gunawardena N. E. \& Bandumathie M.K. (1993). Defensive secretion of rice bug Leptocorisa oratorius (Hemiptera: Coreidae): a unique chemical combination and its toxic, repellent and alarm properties. Journal of Chemical Ecology 19: 851-861.

7. Taylo L.D. \& Litsinger J.A. (1987). Plant host range of the rice bug (RB). International Rice Research Newsletter 12 (2): 36.

8. Gunawardena N.E., Attygalle A.B. \& Herath H.M.W.K.B. (1989). The sex pheromone of the Brinjal pest, Leucinodes orbonalis Guenee (Lepidoptera): problems and perspectives. Journal of the National Science Council of Sri Lanka 17(2): 165-175.

9. Weatherston J. \& Percy J.E. (1978). Venoms of Rhyncota, In Arthropod Venoms, (Ed. S. Battini). pp. 489-509 Springer Verlag, Berlin.

10. Staddon B.W. (1979). The scent glands of Heteroptera. Advances in Insect Physiology 14: 351-418.

11. Gunawardena N.E. \& Herath H.M.W.K.B. (1992). Significance of medium chain $n$-alkanes as accompanying compounds in hemipteran defensive secretions: an investigation based on the defensive secretion of Coridius janus. Journal of the Chemical Ecology 17: 2449-2458.

12. Remold H. (1963). Scent glands of land-bugs, their physiology and biological function. Nature (Lond.) 198: 764-768.

13. Aldrich J.R. \& Blum M. (1978). Aposematic aggregation of a bug (Hemiptera: Coreidae). Biotropica 10: 58-61.

14. Goodchild A.J.P. (1977). Bionomics, aggregated feeding behaviour and colour variations in the sap-sucking bug. Mygdonia tuberculosa Sign. Review Zoology, Africa 91(4): 1032-1041.

15. Blum M.S. (1985). Alarm pheromones, In Comprehensive Insect Physiology, Biochemistry and Pharmacology, (Eds. G.A. Kerkut and L. I. Gilbert) pp. 193-224. Vol 9. Pergamon Press, Oxford.

16. Lockwood J.A. \& Story R.N. (1985). Bifunctional pheromone in the first instar of the Sourthern Green stink bug, Nazara viridula (Hemiptera: Pentatomidae): its characterization and interaction with other stimuli. Annals of Entomological Society of America 78(4): 474-479. 